\title{
Phenotypic correlation and direct and indirect effects of aerial part components with root distribution of common bean
}

\author{
Luis Paulo Saraiva Velho(1), Murielli Sabrina Gemeli(1), Nicole Trevisani ${ }^{(1)}$, \\ Thayse Cristine Vieira Pereira ${ }^{(1)}$, Paulo Henrique Cerutti ${ }^{(1)}$, Rita Carolina de Melo(1), \\ Altamir Frederico Guidolin ${ }^{(1)}$, Jefferson Luís Meirelles Coimbra ${ }^{(1)}$ and Sabrina Cristina Corrêa(1)
}

\begin{abstract}
(1)Universidade do Estado de Santa Catarina (Udesc), Instituto de Melhoramento e Genética Molecular, Avenida Luiz de Camões, no 2.090, CEP 88520-000 Lages, SC, Brazil. E-mail: luispaulosaraivav@hotmail.com, murigemeli@gmail.com, nicoletrevisani88@gmail.com, thayseagro@gmail.com, paulo_cerutti@hotmail.com, rita_carol_mel@hotmail.com, altamirguidolin@gmail.com,
\end{abstract} coimbrajefferson@gmail.com, sabri_cristina@hotmail.com

\begin{abstract}
The objective of this work was to estimate the phenotypic correlation and the direct and indirect effects of the aerial part components of common bean (Phaseolus vulgaris) that are associated with root distribution, in order to facilitate the indirect selection for this character. Sixteen genotypes were used, from which 12 are segregating populations in the $\mathrm{F}_{6}$ generation and four are fixed populations, which were conducted in field conditions in a randomized complete block design, with two replicates. The root system evaluation was performed according to Böhm's method. Pearson's phenotypic correlation was estimated by the path analysis. The characters stem diameter, leaf area index, first pod set, and root angle showed the highest positive correlations with root distribution and, therefore, may help the indirect selection for this character. The residual effect was higher than the determination coefficient, which indicates that the independent characteristics do not have a total influence on root distribution, and the low values of the determination coefficients can be attributed to environmental effects, competition for nutrients, and to different physiological mechanisms that control the expression of several genes with minor effects.
\end{abstract}

Index terms: Phaseolus vulgaris, abiotic stress, indirect selection, path analysis.

\section{Correlação fenotípica e efeitos diretos e indiretos de componentes da parte aérea com a distribuição radicular de feijão-comum}

\begin{abstract}
Resumo - O objetivo deste trabalho foi estimar a correlação fenotípica e os efeitos diretos e indiretos dos componentes da parte aérea do feijoeiro (Phaseolus vulgaris) que estão associados à distribuição radicular, para facilitar a seleção indireta quanto a este caráter. Utilizaram-se 16 genótipos, dos quais 12 são populações segregantes em geração $\mathrm{F}_{6}$ e quatro populações fixas, conduzidas em campo em delineamento de blocos ao acaso, com duas repetições. A avaliação do sistema radicular foi realizada conforme o método de Böhm. A correlação fenotípica de Pearson foi estimada por meio da análise de trilha. Os caracteres diâmetro de caule, índice de área foliar, inserção da primeira vagem e ângulo de raiz apresentaram as maiores correlações positivas com a distribuição radicular e podem, portanto, auxiliar a seleção indireta quanto a esse caráter. $\mathrm{O}$ efeito residual foi superior ao coeficiente de determinação, o que é indício de que as características independentes não têm influência total sobre a distribuição radicular, e os baixos valores dos coeficientes de determinação podem ser atribuídos a efeitos de ambiente, à competição por nutrientes e a diferentes mecanismos fisiológicos que controlam a expressão de vários genes com efeitos menores.
\end{abstract}

Termos para indexação: Phaseolus vulgaris, estresse abiótico, seleção indireta, análise de trilha.

\section{Introduction}

One of the largest bean producers worldwide, Brazil accounts for about $20 \%$ of the world bean production. In 2016, the country produced 2.696 teragrams, in an area of 2.8 million ha, with 955 $\mathrm{kg} \mathrm{ha}^{-1}$ average productivity of, according to Conab (Acompanhamento..., 2016). However, the crop productive potential, under adequate conditions, is greater than $4,000 \mathrm{~kg} \mathrm{ha}^{-1}$. This low productivity has been attributed mainly to abiotic factors, including water deficit. Sixty percent of bean crop worldwide is estimated to grow under dry conditions, which results in the reduction of up to $80 \%$ of grain yield in some regions (Cuellar-Ortiz et al., 2008). In addition, global climate change aggravates the crop water limitation, 
increasing the evaporative demand, accelerating soil degradation, and changing the distribution of rainfall over time and space (Wheeler \& Von Braun, 2013).

The root system architecture is a promise for improving agricultural productivity, which is essential to increase the plant absorption capacity (Wasson et al., 2012; Lynch, 2013, 2015). Thus, several breeding programs focus on genetically manipulating the root system of plants, in order to improve water and nutrient absorption capacity as a way to minimize abiotic effects on grain yield (Dorlodot et al., 2007; Melo et al., 2016). Therefore, the evaluation of characteristics associated with root (distribution, architecture, length, among others) is of extreme importance for plant selection programs.

The root system of common bean is complex, it results from the expression and association of different components, and is highly influenced by the environment effect (Wasson et al., 2012). It is necessary, then, to know the effects that interact in the behavior of the character, in order to obtain a higher efficiency in selection (Kurek et al., 2001). Hence, it is important to estimate the correlation between the root system and the components of the aerial parts. This estimate allows to diagnose the magnitude and direction of relationships between characters, and to assess the feasibility of the use of indirect selection, which can lead to a faster and highly expressive genetic progress for the genetic breeding program (Cruz et al., 2012).

The objective of this work was to estimate the phenotypic correlation and the direct and indirect effects of the aerial part components of common bean that are associated with root distribution, in order to facilitate the indirect selection for this character.

\section{Materials and Methods}

The experiment was carried out in the field, in the 2014/2015 crop season, in the experimental area of the agroveterinary science center (CAV) of Universidade do Estado de Santa Catarina (Udesc), in the municipality of Lages, in the state of Santa Catarina, Brazil $\left(27^{\circ} 47^{\prime} \mathrm{S}, 50^{\circ} 18^{\prime} \mathrm{W}\right.$, at $920 \mathrm{~m}$ average altitude). The climate, according to the classification of Köppen-Geiger, is a humid temperate, mesothermal $\mathrm{Cfb}$, with warm summer. The soil is classified as a Cambissolo Húmico Alumínico léptico (Inceptisol Udepts Humudepts), with a moderate A horizon and clayey texture, in which siltite+argilite substrate is prominent, with undulating relief. The soil shows the following properties: clay, $340 \mathrm{~g} \mathrm{~kg}^{-1}$; water $\mathrm{pH}$, 5.93; potential acidity by SMP, $5.21 ; \mathrm{P}, 10.06 \mathrm{mg} \mathrm{dm}^{-3} ; \mathrm{K}, 80$ $\mathrm{mg} \mathrm{dm}{ }^{-3}$; organic matter, 2.61\%; Ca, $5.42 \mathrm{cmol}_{\mathrm{c}} \mathrm{dm}^{-3}$; and $\mathrm{Mg}, 2.10 \mathrm{cmol}_{\mathrm{c}} \mathrm{dm}^{-3}$.

Soil preparation was performed in a conventional system, with one plowing and two light harrowings. Fertilization was performed based on the results of the soil analysis. No basic fertilization was carried out, except for a $50 \mathrm{~kg} \mathrm{ha}^{-1} \mathrm{~N}$ topdressing fertilization. Phytosanitary management was carried out according to crop requirements, and weed control was performed by manual weeding.

Sixteen common bean genotypes were evaluated, from which four were fixed populations - BAF 50, BAF 009, BAF 007, and 'IPR Uirapuru' -, and 12 were segregating populations in generation $\mathrm{F}_{6}$, originated from a complete diallel cross between the four populations mentioned. A randomized complete block experimental design was carried out with two replicates per treatment. The experimental unit consisted of six rows of $4.0 \mathrm{~m}$, with $0.5 \mathrm{~m}$ spacing between rows, and $0.90 \mathrm{~m}$ between plots. Sowing was done manually, with a density of 10 seed per linear meter, in the four central rows (in which root angle, the components of the aerial parts, and grain yield were evaluated); in the two external rows, $0.5 \mathrm{~m}$ spacing was used between plants, where a profile was opened in the soil parallel to the seeding line.

The evaluation of the root system in the soil profile was performed by the Böhm's method (1979), with modifications. When the genotypes showed full flowering, profiles perpendicular to the seeding line were opened at $0.05 \mathrm{~m}$ from plants, and the roots were exposed with a sharp tool. After that, a $0.5 \mathrm{~m}$ wide and $0.3 \mathrm{~m}$ high rectangle, subdivided into 60 grids cells of $0.05 \mathrm{~m}$, was placed on the soil profile. The profile was photographed for further evaluation of the distribution of the roots, with a camera of $7.2 \mathrm{MP}$, and it was positioned at a standard distance of $60 \mathrm{~cm}$ from the grid. Root distribution was determined in the binary system through digital photography, and scaled (1) for root presence and (0) for root absence in each grid.

The method of Shovelomics, developed by Trachsel et al. (2011), was used to evaluate the root angle. For this, roots were excavated at $25-30 \mathrm{~cm}$ around plant's neck, at a $30 \mathrm{~cm}$ soil depth. After the removal of excess soil, roots were immersed in a vessel with water and 
$0.5 \%$ detergent; subsequently, the material was rinsed with water only, until roots were thoroughly cleaned. The angle of basal roots was then measured using a protractor.

The leaf area index was estimated with an Accupar LP-80 ceptometer (Decagon Devices, Inc., Pullman, WA, USA), which integrates the transmission and the penetration of light with the structural characteristics of the plant, such as the angle and the distribution of the leaves, and it estimates an indirect measurement of the leaf area index. The readings were made on the canopy of plants and below the canopy (at ground level).

When plants reached the harvest-time, five plants of each plot were randomly collected for estimation of plant height (PH), insertion of first pod (IFP), stem diameter (SD), fresh weight of aerial parts (FWAP), root angle (RA), number of pods per plant (NPP), and number of grains per plant (NGP). Leaf area index (LAI) and grain yield (GY) were estimated in the plot area. Data were subjected to the phenotypic correlation analysis by the method proposed by Steel \& Torrie (1980), and were later divided into direct and indirect effects by path analysis (Cruz et al., 2012).

The quantification and interpretation of the correlation coefficient between two characters can cause confusion during the selection, as a high correlation may be due to the effect of a third character, or of a group of characters (Cruz et al., 2012). In order to reduce such problems, Wright (1921) proposed a methodology of path analysis, which unfolds the estimated correlations in direct and indirect effects of characters on a basic variable, which is based on the evaluation of the effect of an independent variable (x) on a dependent one (y), after removal of the influence of all other independent variables.

\section{Results and Discussion}

The phenotypic correlations between the characteristics of the aerial parts and root distribution are presented in Table 1. The magnitude of the correlation coefficients ranged from -0.04 to 0.72 . The characters insertion of first pod (0.40), stem diameter (0.42) and leaf area index (0.38) showed a positive and significant association with the character root distribution. This result is advantageous in breeding programs, since the selection of prominent genotypes for root distribution may be facilitated by the selection of characters with easy phenotyping. Similarly, Bizari et al. (2010) found a linear correlation between leaf area index and root distribution. The other evaluated traits showed no significant effects; thus, it is not possible to carry out an indirect selection based on these characters, as they are not associated with root distribution.

Therefore, the increase of the number of positive and significant characters of the aerial parts with the root system allows the breeder to perform the indirect selection, which may lead to a faster and expressive genetic progress in a breeding program. According to Falconer \& Mackay (1996), one of the causes for high correlations is the occurrence of pleiotropism, which means that a gene is responsible for the expression of more than one character.

For stem diameter, a significant linear correlation coefficient was observed between plant height $(0.38)$ and the first pod set (0.39) (Table 1). This result is important, as it shows that it is possible to identify plants with higher stem diameter, height and high first pod set, and with reduction of bedding. Such characters, thus associated, enable a satisfactory improvement of

Table 1. Correlation coefficients between the phenotypic characters root distribution (RD), plant height (PH), insertion of first pod (IFP), stem diameter (SD), number of pods per plant (NPP), number of grains per plant (NGP), leaf area index (LAI), grain yield (GY), root angle (RA), and fresh weight of aerial parts (FWAP).

\begin{tabular}{|c|c|c|c|c|c|c|c|c|c|}
\hline Character & $\mathrm{PH}$ & IFP & SD & NPP & NGP & LAI & GY & $\mathrm{RA}$ & FWAP \\
\hline $\mathrm{RD}$ & 0.34 & $0.40 *$ & $0.42 *$ & 0.11 & 0.22 & $0.38 *$ & 0.26 & 0.34 & -0.07 \\
\hline $\mathrm{PH}$ & & $0.72 *$ & $0.38^{*}$ & 0.05 & 0.20 & $0.46^{*}$ & -0.05 & 0.23 & -0.11 \\
\hline IFP & & & $0.39 *$ & 0.005 & -0.04 & $0.38 *$ & 0.32 & 0.12 & -0.25 \\
\hline SD & & & & $0.37^{*}$ & $0.54 *$ & 0.06 & 0.07 & 0.20 & -0.34 \\
\hline NPP & & & & & $0.69 *$ & 0.038 & 0.04 & 0.07 & -0.06 \\
\hline NGP & & & & & & 0.1 & 0.06 & 0.34 & -0.22 \\
\hline LAI & & & & & & & 0.15 & 0.10 & 0.09 \\
\hline GY & & & & & & & & 0.21 & -0.31 \\
\hline $\mathrm{RA}$ & & & & & & & & & $-0.52 *$ \\
\hline
\end{tabular}

*Significant at 0.05 probability. 
plant architecture and they facilitate the mechanized harvesting. Stem diameter also showed a correlation with the number of pods per plant $(0.37)$ and the number of grains per plant (0.54). In an improvement program, a balance is sought between the characters studied, in a manner that plant has an ideotype that maximizes grain yield, taking into account the other characters. As an example, an expressive increase in the number of pods cannot be supported by a plant that does not show a parallel increase of stem diameter (Rocha et al., 2009).

The root angle showed a significant and negative correlation with the fresh weight of aerial parts $(-0.52)$. Under restrictive conditions or with low-input crops, the growth of plant aerial parts may be affected. This indicates that the angle of the root system negatively affects the root/shoot ratio. According to Burridge et al. (2016), the production of a larger root volume and root depth leads to a high metabolic cost and energy expenditure by the plant. According to Lynch \& Brown (2008), the root angle (gravitropism) is strongly affected by the environment, mainly due to the low-P availability in the soil, which often causes changes in the root system architecture.

The leaf area index showed a high correlation with plant height (0.46) and the insertion of first pod (0.38) (Table 1); thus, the higher the leaf area index, the higher the photosynthetic rate and plant transpiration that, generally, have greater height, and in which the first pod set is higher. In addition, the plant height and insertion of first pod characters showed the highest linear correlation (0.72).

Although the correlation coefficients are important to quantify the magnitude and direction of the influences of factors in the determination of characters, the study of these correlations do not corroborate the true cause and effect relationships between explanatory variables and the main variable (Cruz et al., 2012). The estimates obtained by path analysis of direct and indirect effects of the characters that influence the variable root distribution, are presented in Figure 1. It is important to identify among the characteristics which show high correlation with the basic variable those with the highest direct effect in favor of the selection, so that the response of indirect selection is efficient.

The insertion of the first pod, stem diameter, leaf area index, root angle, and grain yield exhibited the highest direct effects and correlation coefficients with the root distribution, in comparison with the other evaluated traits. Among the characters involved in the unfolding of correlations, stem diameter (0.435), LAI (0.243), root angle (0.406), and first pod set $(0.227)$ showed a positive correlation and direct effect, in the same direction with the variable root distribution, which allows of an association between these characters (Figure 1). Therefore, the direct selection of these characters is efficient in improving root distribution.

Plant height showed a direct and negative effect $(-0.138)$ on the root distribution; however, it displayed a positive correlation coefficient (0.339). This result was certainly due to indirect effects of the characters first pod insertion (0.163), stem diameter (0.167), LAI (0.111), and root angle (0.095), indicating that the selection truncated at the plant height may not provide satisfactory gains in the variable root distribution (Figure 1). In this case, the best strategy is to select the variables that have significant indirect effects, that is, a combined selection (Oliveira et al., 2010).

Toaldo (2012) studied the correlation between root distribution and aerial parts, and found that stem diameter and height showed greater direct effect on root distribution. Subbarao et al. (1995) observed a negative correlation between the root system and the aerial parts, in conditions of water deficiency, and showed that plants with water stress tend to allocate more photoassimilates to the root system, consequently reducing the aerial parts. Under these conditions, plants will increase the development of the root system as an adaptation mechanism to improve water absorption (Scalon et al., 2011; Gonçalves, 2013).

Leaf area index displayed a total correlation of 0.382 and direct effect of 0.243 on root distribution, which corroborates the results observed by Toaldo (2012). Rocha et al. (2010) observed both positive and negative correlations between root distribution and the LAI, when working with mutant common bean genotypes.

Fresh weight of the aerial parts exhibited a direct effect on root distribution, which was annulled by the indirect negative effects of stem diameter, insertion of first pod, number of grains, grain yield, and root angle, and resulted in a total negative correlation (Figure 1); that is, the indirect effects may be the possible causes of the correlation, by playing a fundamental role at the moment of selection.

Pesq. agropec. bras., Brasília, v.52, n.5, p.328-334, maio 2017 DOI: 10.1590/S0100-204X2017000500006 


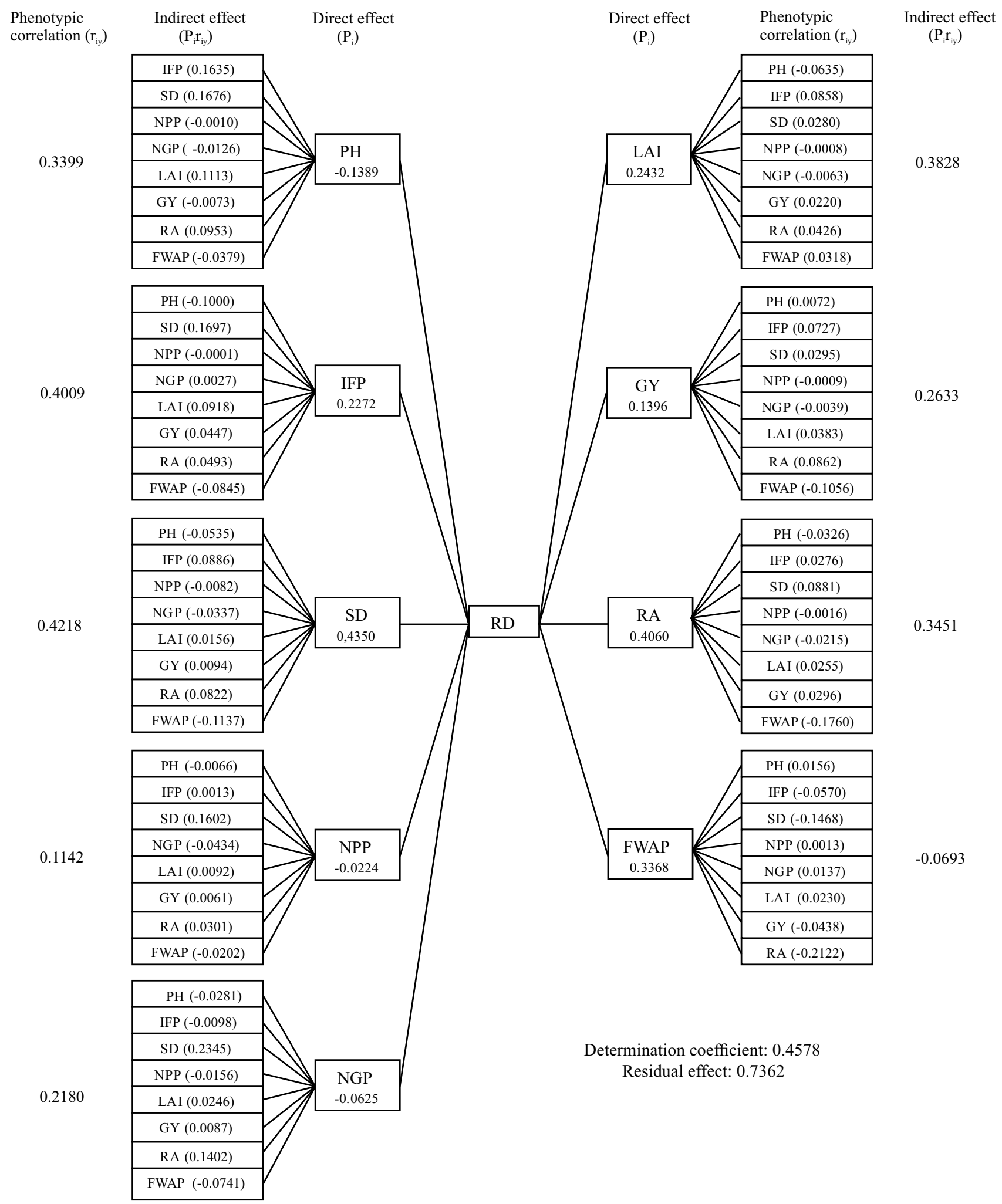

Figure 1. Estimates of direct and indirect effects on the root distribution (RD) by the characters plant height (PH), insertion of the first pod (IFP), stem diameter (SD), number of pods per plant (NPP), number of grains per plant (NGP), leaf area index (LAI), grain yield (GY), root angle (RA), and fresh weight of aerial parts (FWAP). 
Root angle showed a high positive correlation (0.343) and high direct effect (0.390) with the root distribution. In a study by Uga et al. (2013), root angle was directly related to the root system architecture, in which roots with wider angle provided a more widely dispersed and superficial root system with better absorption of nutrients; however, roots with less angulation produced deeper roots, a feature more favorable for water absorption. Beebe et al. (2008) selected genotypes that have a good root distribution, both in the most superficial and in the deeper soil layers, that is, genotypes completely adapted to environments with both water deficit and low-nutrient availability. This indicates that a direct selection, by root angle, can provide satisfactory gains for root distribution and is a less expensive measuring method, in comparidon to the opening of the soil profile to assess roots.

As to the grain yield components, the characters number pods $(-0.062)$ per plant and number of grains per plant $(-0.002)$ had a direct negative effect on root distribution and a low-correlation coefficient of (0.114) and (0.218), respectively (Figure 1). These results indicate that both the direct and indirect selections for grain yield components do not predict a satisfactory gain in root distribution. Toaldo (2012) assessed the correlation of root distribution with the aerial parts, and found that genotypes with high vegetative and root developments tend to spread photoassimilates between these characters, and to reduce them in the characters responsible for productivity increase, which shows that there is a high-energy cost in the production of roots and leaves. Some authors like Beebe et al. (2008) observed that the correlation was positive between productivity and the root system, under water deficit conditions, which suggests that some genes of resistance to drought are expressed under stress conditions.

Grain yield displayed a positive correlation, however, it showed a low direct effect, and this indicates that the character may not provide satisfactory gains in the basic variable. Therefore, the best strategy is a simultaneous selection of characters, with an emphasis on characters whose indirect effects are high and significant (Cabral et al., 2011).

The coefficient of determination $\left(\mathrm{R}^{2}\right)$ showed a lower value $(0.457)$ than the residual effect (0.736), and it shows that the independent variables do not completely affect the entire root distribution. A low coefficient of determination may be related to environmental effects, competition for nutrients, and to different physiological mechanisms that control the expression of the variables. According to Toaldo (2012) and Miguel et al. (2015), root distribution is affected by various factors, both genetic and environmental, such as root architecture, plasticity of root in relation to the availability of water and nutrients, different types of soil, and environmental variations.

\section{Conclusions}

1. The characters stem diameter, leaf area index, insertion of first pod, and root angle show the highest positive correlations with root distribution and can aid the indirect selection.

2. The evaluated common bean populations do not show a complete relationship between characters, which indicates that the best strategy should be the simultaneous selection of characters, with an emphasis on characters with significant indirect effects.

\section{Acknowledgments}

To Universidade do Estado de Santa Catarina (Udesc), to Conselho Nacional de Desenvolvimento Científico e Tecnológico (CNPq), to Coordenação de Aperfeiçoamento de Pessoal de Nível Superior (Capes), and to Fundação de Apoio à Pesquisa Científica e Tecnológica do Estado de Santa Catarina (Fapesc), for scholarship granted and financial support to the development of the present work.

\section{References}

ACOMPANHAMENTO DA SAFRA BRASILEIRA [DE] GRÃOS: safra 2015/16: décimo levantamento, v.3, n.10, jul. 2016. 179p. Available at: <http://www.conab.gov.br/OlalaCMS/uploads/ arquivos/16_07_29_15_12_51_boletim_graos_julho_2016.pdf $>$. Accessed on: Aug. 92016.

BEEBE, S.E.; RAO, I.M.; CAJIAO, C.; GRAJALES, M. Selection for drought resistance in common bean also improves yield in phosphorus limited and favorable environments. Crop Science, v.48, p.582-592, 2008. DOI: 10.2135/cropsci2007.07.0404.

BIZARI, D.R.; MATSURA, E.E; CHAMLET, J.; MESQUITA, M.; SALVADOR,C.A. Profundidade efetiva de raízes e sua relação com a parte aérea da cultura do feijoeiro irrigado em sistema plantio direto. Revista Brasileira de Agricultura Irrigada, v.4, p.172-183, 2010. 
BÖHM, W. Methods of studying root systems. Berlin: SpringerVerlag, 1979. 188p. (Ecological studies, v.33). DOI: 10.1007/9783-642-67282-8.

BURRIDGE, J.; JOCHUA, C.N.; BUCKSCH, A.; LYNCH, J.P. Legume shovelomics: High-throughput phenotyping of common bean (Phaseolus vulgaris L.) and cowpea (Vigna unguiculata subsp. unguiculata) root architecture in the field. Field Crops Research, v.192, p.21-32, 2016. DOI: 10.1016/j.fcr.2016.04.008.

CABRAL, P.D.S.; SOARES, T.C.B.; LIMA, A.B.P.; SOARES, Y.J.B.; SILVA, J.A. da. Análise de trilha do rendimento de grãos de feijoeiro (Phaseolus vulgaris L.) e seus componentes. Revista Ciência Agronômica, v.42, p.132-138, 2011.

CRUZ, C.D.; REGAZZI, A.J; CARNEIRO, P.C.S. Modelos biométricos aplicados ao melhoramento genético. 4.ed. Viçosa: Ed. da UFV, 2012. v.1, p.179-181.

CUELLAR-ORTIZ, S.M.; DE LA PAZ ARRIETA-MONTIEL, M.; ACOSTA-GALLEGOS, J.; COVARRUBIAS, A.A. Relationship between carbohydrate partitioning and drought resistance in common bean. Plant, Cell and Environment, v.31, p.1399-1409, 2008. DOI: 10.1111/j.1365-3040.2008.01853.x.

DORLODOT, S. de; FORSTER, B.; PAGÉS, L.; PRICE, A.; TUBEROSA, R.; DRAYE, X. Root system architecture: opportunities and constraints for genetic improvement of crops. Trends in Plant Science, v.12, p.474-481, 2007. DOI: 10.1016/j. tplants.2007.08.012.

FALCONER, D.S.; MACKAY, T.F.C. Introduction to quantitative genetics. $4^{\text {th }}$ ed. Essex: Longman, 1996. 464p.

GONÇALVES, J.G.R. Identificação de linhagens de feijoeiro (Phaseolus vulgaris L.) tolerantes à seca. 2013. 82p. Tese (Doutorado) - Instituto Agronômico de Campinas, Campinas.

KUREK, A.J.; CARVALHO, F.I.F. de; ASSMANN, I.C.; MARCHIORO, V.S.; CRUZ, P.J. Análise de trilha como critério de seleção indireta para rendimento de grãos em feijão. Revista Brasileira de Agrociência, v.7, p.29-32, 2001.

LYNCH, J.P. Root phenes that reduce the metabolic costs of soil exploration: opportunities for 21st century agriculture. Plant, Cell and Environment, v.38, p.1775-1784, 2015. DOI: 10.1111/ pce. 12451 .

LYNCH, J.P. Steep, cheap and deep: an ideotype to optimize water and $\mathrm{N}$ acquisition by maize root systems. Annals of Botany, v.112, p.347-357, 2013. DOI: 10.1093/aob/mcs293.

LYNCH, J.P.; BROWN, K.M. Root strategies for phosphorus acquisition. In: WHITE, P.J.; HAMMOND, J.P. (Ed.). The ecophysiology of plant-phosphorus interactions. [Dordrecht]: Springer, 2008. p.83-116. (Plant Ecophysiology, v.7). DOI: 10.1007/978-1-4020-8435-5_5.

MELO, R.C. de; SCHMIT, R.; CERUTTI, P.H.; GUIDOLIN, A.F.; COIMBRA, J.L.M. Genetic variation in the trait root distribution over segregating generations of common bean. Euphytica, v.207, p.665-674, 2016. DOI: 10.1007/s10681-015-1568-z.

MIGUEL, M.A.; POSTMA, J.A.; LYNCH, J.P. Phene synergism between root hair length and basal root growth angle for phosphorus acquisition. Plant Physiology, v.167, p.1430-1439, 2015. DOI: $10.1104 /$ pp.15.00145.
OLIVEIRA, E.J. de; LIMA, D.S. de; LUCENA, R.S.; MOTTA, T.B.N.; DANTAS, J.L.L. Correlações genéticas e análise de trilha para número de frutos comerciais por planta em mamoeiro. Pesquisa Agropecuária Brasileira, v.45, p.855-862, 2010. DOI: 10.1590/S0100-204X2010000800011.

ROCHA, F. da; BARILI, L.D.; GARCIA, S.H.; MODENA, R.; COIMBRA, J.L.M.; GUIDOLIN, A.F.; BERTOLDO, J.G. Seleção em populações mutantes de feijão (Phaseolus vulgaris L.) para caracteres adaptativos. Biotemas, v.22, p.19-27, 2009.

ROCHA, F. da; COAN, M.M.D.; COIMBRA, J.L.M.; BERTOLDO, J.G.; GUIDOLIN, A.F.; KOPP, M.M. Root distribution in common bean populations used in breeding programs. Crop Breeding and Applied Biotechnology, v.10, p.40-47, 2010. DOI: 10.12702/19847033.v10n01a06.

SCALON, S. de P.Q.; MUSSURY, R.M.; EUZÉBIO, V.L. de M.; KODAMA, F.M.; KISSMANN, C. Estresse hídrico no metabolismo e crescimento inicial de mudas de mutambo (Guazuma ulmifolia Lam.). Ciência Florestal, v.21, p.655-662, 2011. DOI: $10.5902 / 198050984510$.

STEEL, R.G.D.; TORRIE, J.H. Principles and procedures of statistics: a biometrical approach. $2^{\text {nd }}$ ed. New York: McGrawHill, 1980. 631p.

SUBBARAO, G.V.; JOHANSEN, C.; SLINKARD, A.E.; NAGESWARA RAO, R.C.; SAXENA, N.P.; CHAUHAN, Y.S. Strategies for improving drought resistance in grain legumes. Critical Reviews in Plant Sciences, v.14, p.469-523, 1995. DOI: $10.1080 / 07352689509701933$.

TOALDO, D. Melhoramento do sistema radicular do feijão visando tolerância a deficiência hídrica. 2012. 59p. Dissertação (Mestrado) - Universidade do Estado de Santa Catarina, Lages.

TRACHSEL, S.; KAEPPLER, S.M.; BROWN, K.M.; LYNCH, J.P. Shovelomics: high throughput phenotyping of maize (Zea mays L.) root architecture in the field. Plant and Soil, v.341, p.7587, 2011. DOI: 10.1007/s11104-010-0623-8.

UGA, Y.; SUGIMOTO, K.; OGAWA, S.; RANE, J.; ISHITANI, M.; HARA, N.; KITOMI, Y.; INUKAI, Y.; ONO, K.; KANNO, N.; INOUE, H.; TAKEHISA, H.; MOTOYAMA, R.; NAGAMURA, Y.; WU, J.; MATSUMOTO, T.; TAKAI, T.; OKUNO, K.; YANO, $\mathrm{M}$. Control of root system architecture by DEEPER ROOTING 1 increases rice yield under drought conditions. Nature Genetics, v.45, p.1097-1102, 2013. DOI: 10.1038/ng.2725.

WASSON, A.P.; RICHARDS, R.A.; CHATRATH, R.; MISRA, S.C.; SAI PRASAD, S.V.; REBETZKE, G.J.; KIRKEGAARD, J.A.; CHRISTOPHER, J.; WATT, M. Traits and selection strategies to improve root systems and water uptake in waterlimited wheat crops. Journal of Experimental Botany, v.63, p.3485-3498, 2012. DOI: 10.1093/jxb/ers111.

WHEELER, T.; VON BRAUN, J. Climate change impacts on global food security. Science, v.341, p.508-513, 2013. DOI: 10.1126/science. 1239402

WRIGHT, S. Correlation and causation. Journal Agriculture Research, v.20, p.557-585, 1921

Received on June 2, 2016 and accepted on November 9, 2016

Pesq. agropec. bras., Brasília, v.52, n.5, p.328-334, maio 2017

DOI: 10.1590/S0100-204X2017000500006 